\title{
COMPLEMENTATION (STRATEGIES) IN SUNDANESE
}

\author{
Eri Kurniawan* \\ Universitas Pendidikan Indonesia \\ eri_kurniawan@upi.edu
}

\begin{abstract}
The chief goals of this paper are two-fold: to lay out a range of complex structures in Sundanese and to assess the extent to which Englebretson's (2003) claim regarding the absence of complementation in colloquial Indonesian can be extended to Sundanese, a neighboring language typologically related to Indonesian. In his corpus study, Englebretson argues that the colloquial Indonesian lacks (syntactic) complement clauses and two verbs/clauses can be linked via complementation strategies, including verb serialization and nominalization. Examination of Sundanese complex structures reveals that Sundanese does evince syntactic complementation and elements that Englebretson might analyze as framing elements are demonstrably arguments of a predicate. Englebretson's account therefore cannot be maintained in Sundanese.
\end{abstract}

Keywords: Sundanese, colloquial Indonesian, complementation strategies, complement clauses

\begin{abstract}
Abstrak
Tujuan dari penelitian ini mencakup dua hal: (i) memaparkan pelbagai jenis struktur kompleks (kalimat majemuk) dalam bahasa Sunda; dan (ii) menyelidiki apakah klaim Englebretson (2003) ihwal ketiadaan komplementasi dalam bahasa Indonesia ragam lisan bisa berlaku untuk data bahasa Sunda, yang secara tipologis begitu dekat dengan bahasa Indonesia. Dalam penelitian korpusnya, Englebretson (2003) berargumen bahwa bahasa Indonesia ragam lisan tidak memiliki klausa komplemen (secara sintaksis) dan dua verba/klausa digabungkan melalui strategi komplementasi, di antaranya verba serial dan nominalisasi. Hasil analisis kalimat-kalimat majemuk dalam bahasa Sunda menunjukkan bahwa bahasa Sunda memiliki komplementasi sintaksis dan elemen-elemen yang dalam analisis Englebretson (2003) dapat dikategorikan sebagai elemen framing terbukti merupakan argumen dari sebuah predikat. Oleh karena itu, teori Englebretson dalam bahasa Indonesia tidak dapat dipakai untuk menjelaskan data bahasa Sunda.
\end{abstract}

Kata kunci: bahasa Sunda, bahasa Indonesia ragam lisan, strategi komplementasi, klausa komplemen

\section{INTRODUCTION}

In the literature, the term 'complement clause' typically denotes a component of a multiclausal construction in which a clausal constituent serves as a core argument of a predicate, functioning either as the subject or the object of that predicate (Noonan, 1985, 2007; Givón, 2001), as in the following English examples:

(1) a. [That a frog got into my apartment] really surprised me.

b. I wondered [who broke into my apartment]. 
The bracketed constituents are instances of subject complements (1a) and object complements (1b). Each sentential component receives a theta role from the predicate in the main clause, making it an argument of the predicate.

Another property ascribed to a sentential complement is that it has the internal constituent structure of a clause (Dixon, 2006). It is clear from looking at (1) that the bracketed parts of the sentence meet this requirement, in that they have both a subject and a predicate.

Not all embedded clauses count as complements, however. If such clauses are not arguments of the predicate, they are clearly not complements. Among these are relative clauses, such as (2a) and adverbial clauses, such as (2b).

(2) a. Kim recognized the boy [who stole a wallet in the mall].

b. [When she graduates from school], she'll return to her home country.

Noonan claims that complementation is a universal property of all of the world's languages such that all languages possess a complement clause. However, a closer look at certain spoken languages calls this claim into question (see Cristofaro, 1998, Thompson, 2002, Englebretson, 2003). Moreover, Dixon (1995, 2006) disagrees sharply with Noonan's (1985) claim and contends that not all languages have grammatical complementation. In some languages, 'complementation strategies' are used to express the range of universal semantics which other languages represent by virtue of morphosyntactic means. ${ }^{1}$ These strategies encompass a variety of grammatical resources or mechanisms - non-embedding structures such as verb serialization, relativization, and nominalization-used for expressing a proposition of canonical complement-taking predicates.

Englebretson (2003) proposes that colloquial Indonesian is a language that evinces no grammaticalized complements. Rather, the language employs complementation strategies serving a comparable semantic function as grammatical complements in other languages. An example of a complementation strategy is what Englebretson (2003) analyzes as a serial verb construction, as seen in the following. ${ }^{2}$

\section{(3) ... Kapan ni mulai ngepak Gus.} when this begin AT-pack Gus

'When will you start packing, Gus?' (Englebretson, 2003, p. 64)

A complement analysis of (3) — such as the one advocated by Sneddon (1996) —would argue that mulai 'start' is the matrix verb and ngepak 'pack' is the complement verb. However, Englebretson (2003) takes (3) to be a monoclausal structure. That is, it contains one clause with a complex predicate mulai ngepak. His main objection to the complement analysis is the absence of evidence to suggest that the second verb is in fact a complement of the first one.

Research on complex/multi-clausal structures in Indonesian and Indonesian-type languages has to date been growing (Cole \& Hermon, 1998, 2000, 2005; Arka \& Manning, 1998; Cole, Hermon \& Aman, 2008; Gil, 1997; Polinsky \& Potsdam, 2008; Saddy, 1991 inter alia). To name a few, Arka (2000) examines a range of control structures in Indonesian, focusing largely on the proposed notion of finiteness in Indonesian. Examination on Sundanese complementation is strikingly scant. Hardjadibrata's (1985), Müller-Gotama's (2001), Sudaryat et al.'s (2007) and Kuswari and Hernawan's (2010) work, for example, while providing a general description on Sundanese structures, lacks specific mention or even deliberation of a 
wide range of multi-clausal structures in Sundanese. The present article, therefore, fills this void in our knowledge of Sundanese syntax.

Hence, the focal goal of this article is to delineate complex structures in Sundanese and determine whether Sundanese patterns with the colloquial Indonesian in that it simply employs complementation strategies or it groups with English in having a grammatically defined category of complementation. To that end, the article will first review the typological profile of Sundanese by focusing on its morphosyntactic properties. It will then lay out various structures that parallel to what one takes to be complementation strategies and presents arguments demonstrating that parallel structures in Sundanese are instantiations of grammatical complementation.

\section{SUNDANESE MORPHOSYNTAX}

To set the scene, there are a number of morphosyntactic properties of Sundanese that can also be attested in neighboring languages such as Indonesian, Javanese, and Madurese. First, Sundanese is a predominantly SVO language, where the subject is in pre-verbal position and the object, if any, is in post-verbal position.

(4) Amung meuli hayam.

Amung AV.buy chicken

'Amung bought a chicken.'

(5) Ohang nitah Amung meuli hayam.

Ohang AV.order Amung AV.buy chicken

'Ohang ordered Amung to buy a chicken.'

Second, there is neither case nor overt tense morphology in this language as shown in (4-5). Amung as the subject has exactly the same form as it is as the object. In the same way, meuli in the matrix clause (4) has the same form as it does in the embedded clause (5). It is, therefore, difficult to determine whether the embedded predicate is finite or not.

Another criterial property of Sundanese is that it exhibits the type of marking on verbs that has been referred to as voice marking in Western Austronesian languages (Ross, 2002). Actor voice (AV) morphology typically occurs when the agent of the transitive verb is in subject position(6). AV is marked by a nasal prefix.

(6) Amung miceun runtah.

Amung AV.throw trash

'Amung threw the trash away.'

Meanwhile, Passive Voice (PV) refers to the canonical passive structure, in which a non-actor nominal becomes the grammatical subject of the sentence and the actor NP, when it surfaces, occurs in a prepositional phrase. Typical of passive agents in Indonesian-type languages, the prepositional PVis morphologically marked by the prefix $d i$ - as exhibited in (7).

(7) Runtah di-piceun (ku Amung).

trash PV-throw by Amung

'The trash was thrown away by Amung.' 
The next section will delineate two types of structures according to the existing literature, one prototypically taken as complementation structures and the other arguably classified as complementation strategies.

\section{COMPLEMENTATION: TYPES AND STRATEGIES}

This section presents various types of clausal complements and (purported) complementation strategies attested in the world's languages.

\section{Complementation Types}

There are various kinds of clausal complements even within a single language. In English, for example, there are four principal complement types.

(8) a. [That Kim left the country] disappointed Raul.

(that-clause)

b. [For Kim to leave the country] disappointed Raul.

(infinitive clause)

c. [Kim's leaving the country] disappointed Raul.

(gerund clause)

d. Raul saw Kim [leaving the country].

(participial clause)

Other languages may incorporate a greater or a lesser number of complement types. Irish, for instance, exemplifies only two types: a go-clause and a nominalized complement (Noonan, 2007). The go-clause in Irish is akin to a that-clause in English.

(9) a. Dúirt sé go dtiocfadh sé. said.3SG he COMP come.COND he 'He said he would come.'
b. Is maithliom iad a fheiceáil.
COP good with.me them COMP see.NOM
'I like to see them.' (Noonan 2007, 54)

Noonan (2007) puts forwards different types of clausal complements crosslinguistically attested in the world's languages. First type is what is commonly referred to as a sentence-like (s-like) complement, namely a clausal constituent in which the verb has the same syntactic relation to its subject and other arguments (10b) as it does in the main clause (10a). That is, the verb in an s-like complement behaves morphologically and syntactically as a matrix verb and the argument therein is case-marked in the same way as a matrix argument.

(10) a. Kim is a family man.

b. Raul knows [that Kim is a family man].

S-like complements may come in various types. The bracketed clause illustrated in (10b), which most closely mirrors the root clause in (10a), is indicative. Non-indicative complements are referred to as subjunctives, which differ from indicatives in that subjunctives typically are marked with special conjugation, particle or complementizer. In English, for example, the difference between an indicative (11a) and a subjunctive (11b) lies in its morphology.

(11) a. Sarah insisted that Dave lives with her.

b. Sarah insisted that Dave live with her.

Noonan proposes that only in languages with grammatical tense/aspect can an indicativesubjunctive distinction be found. It appears to be a tenable prediction since Sundanese, lacking tense/aspect in its verbal morphology, does not distinguish subjunctives from indicatives. 
Other common types of clausal complements are verb serialization and parataxis, details of which are to be discussed in the section to follow. Noonan $(1985,2007)$ argues that verb serialization and parataxis may be analyzed as complement structures, a position with which Dixon (1995, 2006) disagrees. Dixon instead treats those two types of constructions as instantiations of complementation strategies.

Next of note is an infinitive complement, which, according to Noonan $(1985,2007)$, resembles a paratactic complement in that both lack an overt subject. A paratactic clause is distinct from an infinitive in allowing the verb to be inflected for subject agreement ${ }^{3}$ and a paratactic structure is not a subordinate clause. ${ }^{4}$ In addition, paratactic complements may not countenance a complementizer. Further elaboration and example will be presented in the next section.

A nominalized complement differs from other complement types because it has an internal structure of a noun phrase. In the English example (12), the verb beat gets nominalized, taking on a verbal noun form and its argument the thug occurs as a genitive with the nominalized verbal as head noun. Articles, case markers and adpositions may appear with the nominalized predicate.

(12) [The thug's beating of an old man] is being investigated by the local police.

Both the notional subject the thug and object an old man have a genitival relation with the nominalized predicate as coded by 's and $o f$, respectively. Again, Dixon $(1995,2006)$ rejects the analysis of nominalization as complementation by arguing that nominalization is a complementation strategy.

Noonan's $(1985,2007)$ last type is a participial complement, whose role is somewhat restricted. The reason is that being adjectival/adverbial verbs, participials serve to modify some noun, which acts as the head. The only place where participials normally occur as clausal complements is with immediate perception predicates such as see.

(13) a. Ahmad saw a beautiful girl crossing the street.

b. Ahmad saw a beautiful girl cross the street.

The English participial structures above code voice distinctions to reflect aspectual contrasts. What follows is a description of what Dixon $(1995,2006)$ takes as complementation strategies, which he claims are attested in a number of languages.

\section{Complementation Strategies}

In the great majority of the world's languages, verbs like see, know, believe, and want select for either an NP or a clausal complement.

(14) a. Sarah believes [Kim's apology].

b. Sarah believes [that Kim was sorry for what she had done].

However, contra Noonan's $(1985,2007)$ claim of complementation being a universal property of the world's languages, Dixon $(1995,2006)$ argues that there are languages for which complementation is not a syntactic category. These languages have other mechanisms, which he refers to as complementation strategies, to enable them to express complementation meanings. These strategies comprise serial verb constructions, relative clauses, nominalizations, and clause linkage. Whether or not Sundanese exhibits complementation strategies will be examined in subsequent chapters. 


\section{Verb Serialization}

A serial verb construction (henceforth SVC) is a structure in which more than one (typically two) verbs come together to function as one predicate, and thus encode one single event. To a certain extent, a SVC is similar to a monoverbal clause. Dixon (2006) cites the following properties of a SVC.

(15) a. there is no marker or conjunction (e.g. coordination, subordination);

b. there is no intonation or pause break between SVC components;

c. the verbs share one argument, tense, aspect, mood, modality, illocutionary force and polarity value; and

d. the verbs constitute subparts of a single event.

Muysken and Veenstra (1995, as cited in Johnson, 2006) lists two additional characteristics of a SVC, namely (i) the two (or more) verbs have one overt direct object; and (ii) the verb can only have one possible negator. Along the same line, Bisang (2001) defines verb serialization as the unmarked juxtaposition of more than one verb (phrase), with or without an actor/undergoer, and each verb can form its own sentence outside of the SVC. The following is an example from Taba (Bowden, 2001).

(16) $n=$ babas welik $n=m o t$ do

$3 \mathrm{SG}=$ bite pig $\quad 3 \mathrm{SG}=$ die real

'It bit the pig dead'

The SVC in (16) represents one event, i.e. the pig died during the act of biting. The same set of verbs can occur in a coordination structure, showing that each verb can stand on its own, forming a sentence. Thus, (17) is not an SVC.

(17) $n=$ babas welik $n=h a-m o t \quad$ i

$3 \mathrm{SG}=$ bite pig $3 \mathrm{SG}=$ CAUS-die $3 \mathrm{SG}$

'It bit the pig and killed it.' (Bowden, 2001, pp. 297-298)

Bowden (2001) describes (17) as encoding two events in which the death of the pig came about as an indirect result of biting, but the death itself was not necessary, contrary to (16).

In his corpus-based study, Englebretson (2003) contends that colloquial Indonesian also contains no true complementation but does have structures similar to Taba.

(18) Aku juga malas makan.

1SG also lazy eat

'I don't feel like eating either.' (Englebretson 2003, 128)

In (18), two verbs are adjacent and no element can be interposed. The two verbs malas 'be lazy' and makan 'eat' are just juxtaposed in one intonational unit. A complement analysis would then argue that malas makan is a subordination structure in which the verbs are located in two different clauses, malas in the matrix and makan in the embedded, serving as a complement to malas. Englebretson (2003) indeed identifies evidence of overt connectors, e.g. terus 'then' and untuk 'to', between the two verbs in what he claims is a SVC, despite its low frequency in the corpus.

\footnotetext{
(19) a. kapling terus tidur. divide.up then sleep 'I divided it up and then slept.'
} 


\section{b. Di-paksa untukngerubut ke situ to}

PV-force PURP AV.crowd.around to there PART

'They force you to join the crowd there.' (Englebretson 2003, 140)

The occurrence of any overt connectors in a purported SVC contravenes one of the defining properties of verb serialization, that is, no intervening connectors between the two verbs (Foley \& Olson, 1985). In spite of this, however, Englebretson (2003) prefers to treat such cases as exceptions.

\section{Relativization}

According to Dixon (1995, 2006), a second strategy that a language lacking syntactic complementation may employ to express complementation is relativization. To illustrate, consider the following examples from English.

(20) a. They love [the boy [(who is) selling popcorn in the theater]].

b. They love [the boy ('s) selling popcorn in the theater].

The relative clause (who is) selling popcorn in the theater serves to supply extra information regarding the boy. (20a) indicates that they love the boy who happens to be selling popcorn and there is no indication about whether they also love what the boy is doing. In (20b), by contrast, what they love is the activity of selling popcorn in the theater that the person who is doing the selling happens to be a boy. And, the bracketed constituent in (20b) is an instance of a complement structure. Observe that neither who is in (20a) and 's in (20b) is obligatory, making the two structures indistinguishable. In a language such as Dyirbal, such a distinction is not found.

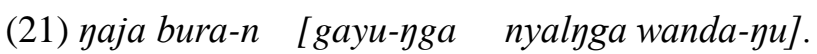

1SG see-PAST cradle-LOCA child hang-REL

'I saw the child hanging in a cradle.' (Dixon, 2006, p. 35)

The sentence above is ambiguous between a relative clause reading (I saw the child who was hanging in a cradle.) and a complement clause reading (I saw the child's hanging in a cradle.). Whether the emphasis of what I saw lies on the child (relative clause) or the event of hanging in a cradle can only be resolved in the discourse context. Therefore, Dixon (2006) conjectures that a language that fails to distinguish between a relative clause and a complement clause may lack syntactic complementation.

\section{Nominalization}

According to Dixon (1995, 2006), nominalization is yet another strategy that can be used to describe a proposition typically expressed via syntactic complementation in many languages. Compare the following English sentences.

(22) a. [Kim's playing a flute] pleased his wife.

b. [Kim's playing of a flute] pleased his wife.

The only noticeable difference between the two sentences is the appearance of the preposition of in (22b), an instance of nominalization. In Dixon's $(1995,2006)$ framework, $(22 b)$ should be necessarily differentiated from (22a), which is an apparent case of complementation. The different meanings of the two structures in question confirm the necessary distinction. In (22a), 
Kim's wife was excited about Kim, who in the past might dislike playing a flute, whereas (22b) his wife was happy because of the way Kim was playing it.

Languages that have no complement clauses like Kham, a Tibetan language (Watters, 2002 cited in Dixon 2006), will utilize nominalization as a complementation strategy. (23) exemplifies nominalization in Kham.

(23) ya: a-to [cuh-si-u] ya-pəż-zya

1SG PROX-SUPERESS sit-middle-NOML 1SG-want-CONT

'I want to sit here/on this.' (Dixon 2006, 37)

The null subject of the nominal constituent $c u h$-si-u marked by the nominalizer $u$ has to corefer to the matrix subject. It should be noted that the English paraphrase is expressed in a complement structure. Dixon (2006) reports that the same nominalization strategy is also attested in Akkadian, Tariana, Goermai, and Matses.

\section{Clause linkage}

Dixon includes two complementation strategies subsumed under the clause linkage category: parataxis and purposive linking.

\section{Parataxis}

Noonan $(1985,2007)$ and Dixon (2006) differ in their assessments of parataxis, which refers to a complex structure containing two independent clauses that are semantically parasitic. Noonan lists a number of defining characteristics of a paratactic construction, which he takes to be a case of complementation.

(24) a. It consists of a subject NP followed by verb phrases;

b. Each verb phrase is fully inflected;

c. There is no complementizer or any marker of subordination;

d. There are no special verb forms.

Noonan (2007) mentions that paratactic constructions are common in African languages such as Luo. In this language, paratactic constructions occur typically with causative predicates whose complements are implied to be true (Creider, 1974, as cited in Noonan, 2007, p. 66).

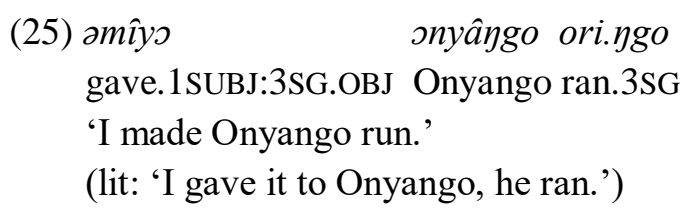

The predicates in paratactic constructions are like canonical CTPs in that they can be inflected. In (25), we see that the verbs exhibit number and person agreement with the notional subject. Noonan (2007), therefore, takes (25) to be a complement structure.

Dixon (2006), on the other hand, proposes that parataxis must be categorized as a complementation strategy. In parataxis, more than one verb (typically two) come together as a sequence, typically thought to encode a single event. In some languages, two clauses are simply juxtaposed. The following illustration comes from Kiowa, a native American language (Watkins, 1984, as cited in Dixon, 2006, p. 20). 
(26) à-ว́n mágyá èm-khoóydé-t’ò

1SG-think+that might 2SG-turn.back-FUT

'I thought that you might turn back'

(lit: 'I think that; you might turn back.')

Dixon (2006) claims that there is no evidence to suggest that the Kiowa analog of (you) might turn back is the complement of I thought. What we see here, instead, are two clauses being apposed. The same line of reasoning is pursued by Englebretson (2003), who analyzes Indonesian constructions such as (27) as juxtaposed clauses "in which one clause serves as a frame for one or more additional clauses which impose specific material into that frame" (p. 46).

(27) ingat-kan dari rumah, jangan bawa duit.

remember-APPL from house don't bring money

'Remind me at home not to bring money.'

Englebretson (2003) maintains that there is no reason to assume that jangan bawa duit 'don't bring money' should be analyzed as subordinated to, embedded in, or the grammatical complement of the first verb ingatkan 'remind'. The first clause sets up a frame, a generic event, which is further specified by the second clause.

\section{Purposive Linking}

Observe the following sentences.

(28) a. [I ran] [(in order) to catch the Hawkeye-Interdorm cambus].

b. [I wanted [to catch the Hawkeye-Interdorm cambus]].

Being an intransitive verb, run does not select a complement. Therefore, without the purpose clause in order to catch the Hawkeye-Interdorm cambus, the sentence remains well-formed. The purpose clause simply serves to offer additional information for why I ran. The verb want, on the other hand, is a transitive verb, which necessarily takes a complement. If the complement clause to catch the Hawkeye-Interdorm cambus is omitted, the sentence is rendered ill-formed. Thus, syntactically, there is a significant difference between these two structures (28a-b).

Some languages employ a purpose clause as a complementation strategy and consequently miss a distinction such as the one illustrated in (29). In such a language, no such apparent differences can be found. Dixon (2006) claims that this is true of Akkadian and Dyirbal. In Dyirbal, for instance, the verb want, or the Dyirbal equivalent walygarray, which precisely means 'want to do something to satisfy a persistent emotional worry or desire', takes a purposive linking strategy.

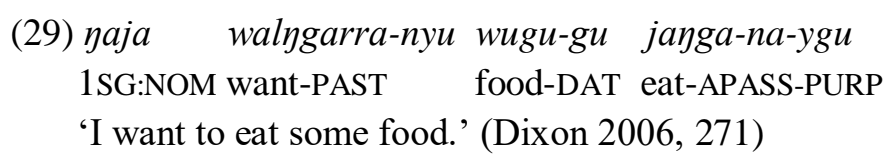

Walygarray is different from the corresponding desiderative verbs in English such as want because walygarray is an intransitive verb, hence does not take another argument. Another Dyirbal verb that takes a purpose clause is ask, or yanba.

(30) yaygu-na ba-ygu-l yanba-n yanu-li

1 sg-ACC there-ERG-MASC ask-PAST go-PURP

'He asked me to go.' (Dixon 2006, 271) 
In this respect, Dixon (2006) points out that (30) is composed of two underlying clauses, namely yayguna baygul yanban 'he asked me' and yaja yanuli 'for me to go'. Dixon then recapitulates that a language lacking a wide range of syntactic complementation may use various complementation strategies including purposive clause linking.

In summary, I have discussed two contested accounts, namely the universality of complements (Noonan, 1985, 2007) and complementation strategies (Dixon, 1995, 2006; Englebretson, 2003). In the subsequent section, I will employ the criterial properties from each account to first enumerate types of Sundanese complex structures and then examine the extent to which Englebretson's claim can be maintained to account for the Sundanese data.

\section{SUNDANESE COMPLEMENTATION (STRATEGIES)}

Adopting Noonan's and Dixon's framework, this section presents complex structures that are crosslinguistically referred to as complementation structures and those which Dixon or Englebretson may analyze them as complementation strategies.

\section{Sundanese Complementation}

As is the case in many of the world's languages, Sundanese has a range of clausal complement types, lending further evidence to Noonan's claim of the universality of (syntactic) clausal complementation in the world's languages.

The yén-clause is analogous to the English that-clause.
(31) [Yén Ujang kabur ti imah] nga-genjleng-keun masarakat. COMP Ujang escape from home AV-uproar-KEUN society
'That Ujang ran away from home caused uproar in the neighborhood.'
(32) Kuring percaya [(yén) manéhna geus meunang gawé].
I believe COMP he PERF win job
'I believe that Ujang has secured a job.'

Notice that the complementizer yén is obligatory in (31) and optional in (32), much like the English analogues. When the complementizer is absent in (33), the strings in italics can be construed as an instance of a canonical (finite) complement clause with a null complementizer, as in (33a), or a case of subject-to-object raising, where manéhna has arguably raised from the embedded subject position to the matrix clause (33b). Only when a complementizer appears does the indeterminacy disappear.

(33) Kuring percaya manéhna geus meunang gawé.

I believe he PERF win job

a. 'I believe that he has secured a job.'

b. 'I believe him to have secured a job.'

Like English, there appears to be infinitive clauses (34) and nominalized clauses (35). However, the absence of overt tense morphology as outlined earlier renders finite/nonfinite verbs indistinguishable.

(34) Bapa maréntah Ujang [sina kabur ti imah]. father AV.order Ujang so that escape from home 'Father ordered Ujang to run away from home.' 
(35) [Kabur-na Ujang ti imah] nga-genjleng-keun masarakat. escape-DEF Ujang from home AV-uproar-KEUN society 'Ujang's running away from home caused uproar in the neighborhood.'

It is unclear whether the bracketed clausal constituent in (34) can be deemed an infinitive clause given the lack of morphosyntactic finiteness vs. non-finiteness distinctions in Sundanese (see Kurniawan, 2013 and Kurniawan \& Davies, 2015 for a more extensive discussion). In (35), the appearance of the definite morpheme (or nominalizer) -na to the right of the complement verb is actually what crucially makes the whole clausal constituent a nominalized complement.

Sundanese seems to lack participial clauses, since the language has no participial morphology.

(36) Ujang manggih-an ba-baturan kamar-na keur nga-dahar pizza sésa]. Ujang AV.find-AN RED-friend-AN room-DEF PROG AV-eat pizza leftover

a. 'Ujang found his roommate eating the leftover pizza.'

b. 'Ujang found (that) his roommate was eating the leftover pizza.'

c. 'Ujang found his roommate who was eating the leftover pizza.'

Example (36) is structurally ambiguous since it can be interpreted as a participial structure (36a), a complement clause with a covert yén (36b), or a (unmarked) relative clause structure (36c). The similar participial/relative clause ambiguity is true of English, since the relativizer who and the copula are omissible. English, however, has the apparatus to encode the participial nature of the verb through its verbal morphology.

In addition, Sundanese displays another kind of construction analogous to a yén-clause.

(37) Aya wartosti pun anak [(wi)réhna nembe kantor désa ka-huruan]. there news from PART child COMP just.now office village PV-fire 'There is news that the village's office just caught fire.'

A similar example exhibiting a yén-clause equivalent from a naturalistic data is shown below.

(38) “... dinten ieu simkuring nampi sms ti kang Gunawan [wiréhna ... day this I AV.receive sms from brother Gunawan COMP mertua anjeunna ngantun-keun ..."

parent-in law he AV.leave-KEUN

'... today I received a text message from Gunawan [that his parent-in-law passed away] ..."

(https://www.mailarchive.com/search?l=urangsunda@yahoogroups.com\&q=subject:\%22RE\%5 $\mathrm{C} \% 3 \mathrm{~A}+\% 5 \mathrm{C} \% 5 \mathrm{BUrang}+\mathrm{Sunda} \% 5 \mathrm{C} \% 5 \mathrm{D}+$ Inalilahi+wainailaihi+rojiun\%22\&o=newest $\& \mathrm{f}=1$ )

(wi)réhna/wiréh and yén are in complementary distribution and semantically they are synonymous.

The conjunctive elements supaya, sangkan, ngarah, and pikeun function as sina since they are able to occur with control predicates.

(39) a. Maranéhna di-titah [sangkan mikeun ngaran ka éta patung-patung]. they PV-order so that AV.give name to that statue-RED 'They were ordered to name those statues.' (http://abufarraz.files.wordpress.com/2012/04/kitab-tauhid-2012.pdf) 
b. Budak téh keur di-olo [ngarah daék dahar bubuahan]. child PART PROG PV-persuade so that want eat RED.fruit 'The kid is being persuaded so that he wants to eat fruits.'

c. Urang di-tungtut [supaya muka deui kisah katoatan Nabi Ibrahim]. we PV-demand so that AV.open again story faith Prophet Ibrahim 'We are demanded to revisit the story of the faith of Prophet Ibraham.' (http://pokjaluhcianjur.blogspot.com/2011/10/khutbah-iedul-adha1432h.html)

d. Anjeun di-pénta [pikeun nulis-keun kecap aksés]. you PV-ask so that AV.write-KEUN word access 'You are asked to write the word 'access'.' (http://www-support-downloads.sonymobile.com/st15/userguide_SU_ST15_12520187.1.pdf)

All these complementizers are interchangeable in most contexts, for they are semantically analogous. ${ }^{5}$

\section{Complementation Strategies in Sundanese}

Two dissimilar types of structures that Englebretson (2003) analyzes as complementation strategies are to be discussed in this section. These include verb serialization and nominalization. Defining characteristics of each structure will be fleshed out and employed to examine corresponding structures in Sundanese. Arguments in favor of a (syntactic) complementation analysis will be presented.

\section{Verb Serialization}

As stated earlier, Englebretson (2003) takes the structure below as an instance of verb serialization, for no conjunction intercedes between the first and second verb.

(40) Aku juga malas makan.

1SG also lazy eat

'I don't feel like eating either.'

The Sundanese parallel of (40) is given in (41). Notice that, as is the case in Indonesian, an optional overt connector can occur between the two verbs. Also note that the subject argument is omissible, characteristic of a spoken Indonesian-type language.

(41) (Kuring) ogé horéam (pikeun) barang dahar.

1SG also lazy PART eat

'I don't feel like eating either.'

Thus, the surface strings of two verbs in Sundanese and Indonesian cannot be argued to be cases of verb serialization due to the fact that a connector may appear between the two verbs.

Another example identical to (41) is illustrated in (42). This construction is what is often referred to as 'control', whereby the matrix argument manéhna 'he' controls the reference of the unpronounced subject in the embedded clause, represented in the following example by a hyphen.

(42) Manéhna hayang [__ milu ulin ka Bebedahan].

he want join play to Bebedahan

'He wants to come along (with us) to go to Bebedahan.' 
In this case three verbs, i.e. hayang 'want', milu 'come along', and ulin 'hang out' occur in sequence without an overt connector. They also happen to share one single argument, namely manéhna 'he'. These characteristics seem to suggest that (42) may well be an instance of verb serialization.

One of the characteristics of serial verb constructions is that the verbs share one negation. This is not what we see in purported serial verb constructions in (43), where the second verb can be independently negated.

(43) Manéhna hayang [__teu milu ulin ka Bebedahan].

he want NEG join play to Bebedahan

'He wants not to come along (with us) to go to Bebedahan.'

To recap, in this sub-section I have shown that purported serial verb constructions in Sundanese that strikingly resemble those in the colloquial Indonesian are clausal complement clauses. The fact that overt connectors and intervening negation can intercede between the initial verb and the second verb furnishes evidence that Englebretson's analysis does not apply to Sundanese.

\section{Nominalization}

Englebretson $(2003,153)$ claims that the colloquial Indonesian exhibits so-called epistemic nya constructions, which constitute semantic and pragmatic functions comparable to grammatical complementation in other languages. Some of the functions comprise evidentiality (source of knowledge), assessment of interactional relevance (degree of value of the contribution to the conversation), or stance (mental/emotional attitude) toward the proposition. Epistemic -nya constructions are taken to exemplify a complementation strategy. ${ }^{6}$ The following is illustrative.

(44) ...pokok-nya bukan minum bir aja. basic-nya NEG drink beer just 'the thing is, they weren't just drinking beer.' (Englebretson, 2003, pp. 155-156)

One analysis would treat (44) as an equational clause in which pokok-nya 'the main thing' provides an epistemic frame for the remainder of the clause. Alternatively, Englebretson (2003) suggests an adverbial analysis, taking nominalized elements such as pokok-nya as an adverbial marker. Chief support for this claim comes from the distribution of such elements within a sentence. (45) shows that a nominalized element, like an adverb, can occur in various locations in a sentence: a sentence-initially (45a), sentence-internally (45b) and sentence-finally (45c).

(45) a. Kayak-nya enak.

like-nya delicious

'It sounds delicious.'

b. mati kayak-nya jam Mega.

dead like-nya watch Mega

'My watch seems to have stopped.'

c. Film bagus tuh horor kayaknya.

film good PART horror like-nya

'It seems to be a good horror film.' (Englebretson, 2003, p. 177) 
Englebretson (2003) points out that the nominalized element kayak-nya 'seemingly' functions as a general evidential marker, which encodes inferred knowledge based on general perception. Such evidential meaning is typically expressed via syntactic complementation as illustrated in the English paraphrases.

It is possible for nominalized elements to co-exist in a sentence. In this example, more than one epistemic - nya frames a single utterance.

(46) Pokoknya berat itu lho kayaknya.

main-nya heavy DEM PART seem-nya

'The thing is, that seems really difficult.' (Englebretson, 2003, p. 185)

According to Englebretson (2003), the functional similarities between -nya constructions and grammatical constructions in other languages lie in their function to frame a clause. However, given their adverbial nature, $-n y a$ constructions are best treated as a complementation strategy in which a nominalized element is used as the framing element, which is embedded into the framed clause as an adverb.

There are analogues of the Indonesian epistemic -nya constructions in Sundanese, the behaviors of which are similar to those of Indonesian.

(47) a. Pasti-na manéhna boga jabatan penting di kantor-na. certain-DEF he own position important in office-DEF

b. Manéhna pasti-na boga jabatan penting di kantorna.

he certain-DEF own position important in office-DEF

c. Manéhna bogajabatan penting di kantorna pasti-na.

he own position important in office-DEF certain-DEF

'Certainly, he (certainly) has an important position at his office (certainly).'

This nominalized element pasti-na carries epistemic meaning. That is, it involves speaker's knowledge or judgment of the truth value of propositions. As the English corresponding paraphrase indicates, this nominalized element appears to act like an adverbial marker as evidenced by its distribution within a sentence, which seems to support Englebretson's analysis of epistemic - nya in Indonesian.

Rather than following Englebretson (2003), however, I would like to propose that the adverbial behavior of nominalized constructions does not necessarily argue for the position that nominalization is a complementation strategy. Support for this emerges from English, which has been categorized as a language with syntactic complementation (see Bresnan, 1970, 1972). English has a number of adverbs whose function is on a par with the prototypical complementation. Observe the following.

(48) a. It is obvious that too many people claim to be religious.

b. Obviously, too many people claim to be religious.

(48a) exemplifies a clausal complement structure with a that-clause being the complement of the predicate obvious. (48b), on the other hand, is a monoclausal structure, which is semantically analogous to (48a). What makes (48b) distinct is the fact that obvious occurs adverbially, suffixed by the adverb of manner modifier. Other predicates that behave in the same way include clear/clearly, possible/possibly, report/reportedly, decide/decidedly, predict/predictably and many others. The fact that certain predicates operate adverbially cannot 
be cited as evidence for complementation strategies or the lack of syntactic complementation in the language. It is more reasonable to assume that a particular set of nominalized elements in Sundanese act as adverbial markers.

Besides the adverbial nominalized elements, Sundanese exemplifies a variety of nominalized clausal complements.

(49) a. Komnas

HAM

masih kénéh nalungtik penémbakan national.commision human rights still AV.investigate shooting pulisi ka Dadap. police to Dadap

b. Komnas HAM masih kénéh nalungtik némbak-na
national.commision human rights still AV.investigate AV.shoot-DEF
pulisi ka Dadap.
police to Dadap

\author{
c. Komnas HAM masih kénéh nalungtik di-témbak-na \\ national.commision human rights still AV.investigate PV.shoot-DEF \\ Dadap ku pulisi. \\ Dadap by police
}

'The human rights committee is still investigating the police's shooting of Dadap.'

The nominalized structure in (49a) contains the deverbal noun penémbakan 'shooting' that precedes the actor of the shooting and the undergoer. The one in (49b) behaves somewhat similarly with that in (49a) insofar as the word order is concerned; the nominalized verb precedes the shooter and the victim. In (49c), the victim of the shooting Dadap comes before the shooter pulisi 'police'. Crucial in (49b-c) is the fact that the voice marking on the nominalized verb is retained and the nominalized verb selects for arguments, indicating that Sundanese nominalized structures correspond to canonical complement clauses.

\title{
Lack of Morphology
}

Englebretson (2003, p. 69) takes the lack of verbal morphology as a cue to the lack of syntactic complementation in Indonesian. Drawing on Givón's (2001, p. 39) definition of a complement, which states: "Defined in the broadest semantic terms, verbal complements (V-Comp) are clauses that function as subject or object arguments of other clauses", Englebretson (2003) contends that for a constituent to count as a complement, it has to meet the syntactic criteria of a subject or an object. He claims that such criteria are not obvious in the colloquial Indonesian. In particular, a grammatical distinction various types of argument, specifically a grammatical category of an object, has been a matter of controversy.

Englebretson (2003) catalogs a host of 'verbs with no-patient trigger form', including tahu 'know', percaya 'believe', sadar 'be aware', ingat 'remember', berpendapat 'have the opinion', berpikir 'think', lupa 'forget', beranggapan 'consider', yakin 'be sure', and berharap 'hope'. Verbs of this type can be followed by NPs, predicates and clauses, which semantically behave like objects but lack the grammatical properties of objecthood, as in example (50).

(50) a. Semua anak-anak tahu jurus-nya.

all child.REDUP know strategy-nya

'All the children know the strategy.' 
b. *Jurus-nya di-tahu oleh semua anak-anak. Strategy-nya PT-know by all child.REDUP (Englebretson, 2003, p. 72)

Englebretson (2003) argues that the lack of passive forms for these verbs suggests that the constituent that immediately follows the verbs is not an object or a complement, but rather a juxtaposed phrase/clause. In fact, verbs such as tahu may have a passive form, as noted by Englebretson (2003, p. 72).
(51) Jurusnya
di-ketahu-i
oleh semua anak-anak.
Strategy-nya PT-NONVOL-know-APP by all child.REDUP
'The strategy is understood by all the children.'

The active form of di-ketahui, however, is not tahu. The active counterpart of (51) would be:

(52) Semua anak-anak me-ngetahu-i jurus-nya.

all child.REDUP AT-NONVOL-know-APP strategy-nya

'All the children understand the strategy.'

Furthermore, there is syntactic evidence that jurusnya 'the strategy' that co-occurs with mengetahui 'know' is in fact an object, as apparent via relativization. It has been standardly assumed that non-subject arguments cannot be relativized (cf. Sneddon 1996, 286), except through passive structures.

(53) Tetapi, ... mencoba berkata, tentang hal yang saya ke-tahu-i.

but AT-try say about thing REL 1SG AT-NONVOL-know-APP

'But I try to talk about things I understand.' (Englebretson, 2003, pp. 72-73)

In this case, hal 'things' is apparently an object, for it can be clefted through a bare passive structure. Englebretson remarks that objecthood can be pinned down only when the verb includes some morphology such as meN-/ $i$. He therefore concludes that the absence of morphological and syntactic cues to tell whether a particular element functions as an object with verbs like tahu suggests that the element in question is just a framing element.

Like Indonesian, Sundanese has a handful of unmarked active verbs, analogues of the Indonesian 'verbs with no-patient trigger form'. These verbs can take an NP or a clause.

(54) a. Sakabéh barudak nyaho jurus-na.

all children know strategy-DEF

'All the children understand the strategy.'

b. Sakabéh barudak nyaho yén jurus-na geus di-robah. all children know COMP strategy-DEF PERF PV-change

'All the children understand that the strategy has been altered.'

(55) a. Pasén téh inget-eun deui kana masalah-na. patient PART remember-3 again to problem-DEF

'The patient remembers her problem.'

b. Pasén téh inget yén masalah-na kudu gancang di-bérés-keun. patient PART remember COMP problem-DEF must soon PV-finish-KEUN 'The patient remembers that her problem needs to be solved soon.'

As is true of the colloquial Indonesian, structures in (54-55) have no passive counterparts, as apparent from the ungrammaticality of the following (56-57). 
(56) a. *Jurus-na di-nyaho ku sakabéh barudak. strategy-DEF PV-know by all children 'All the children understand the strategy.'

b. *Yén jurus-na geusdi-robah di-nyaho ku sakabéh barudak. COMP strategy-DEF PERF PV-change PV-know by all children 'All the children understand that the strategy has been altered.'

(57) a. *Masalah-na di-inget deui kupasén téh. problem-DEF PV-remember again by patient PART 'The patient remembers her problem.'

b. *Yén masalah-na kudu gancang di-bérés-keun di-inget ku pasén téh. COMP problem-DEF must soon PV-finish-KEUN PV-remember by patient PART 'The patient remembers that her problem needs to be solved soon.'

Englebretson (2003) may take structures in (54-55) as indeterminate, and thus the absence of morphological and syntactic cues to signal the objecthood or the complement status of the element following the verb may indicate that such an element is a framing element, not an object/a complement. I would like to argue, contrary to what Englebretson may claim, that relativization works consistently in distinguishing whether an argument is a subject or an object. Since Sundanese does not contain a bare passive structure, when a verb does not have a passive form, relativization will be impossible. The following provides a contrast between subject and object relativization with the verb nyaho and inget.

(58) a. Sakabéh barudak nyaho jurus-na.

all children know strategy-DEF

'All the children understand the strategy.'

b. Sakabéh barudak nu nyaho jurus-na geus baralik ka imah-na. all children REL know strategy-DEF PERF PL.return to house-DEF 'All the children who understand the strategy have returned to their home.'

c. *Jurus-na nu sakabéh barudak nyaho geus teu di-paké deui. Strategy-DEF all children know PERF NEG PV-use again 'It is the strategy that all the children understand.'

(59) a. Pasén téh inget deui kana masalah-na. patient PART remember again to problem-DEF 'The patient remembers her problem.'

b. Pasén nu inget deui kanamasalah-na téhgeus di-bawabalik. patient REL remember again to problem-DEF PART PERF PV-bring return 'The patient who remembers her problem has been taken home.'

c. *Masalahnu pasén inget deui téh geus di-bérés-keun. problem REL patient remember again PART PERF PV-finish-KEUN 'It is the problem that she remembers.'

The fact that there is a contrast between a subject and an object with regard to relativization as exemplified in (58-59) troubles Englebretson's (2003) framing-based analysis. The contrast provides evidence that (i) Sundanese furnishes a syntactic cue to indicate whether an NP is a 
complement (a subject or an object); and (ii) elements that intermediately follow 'bare verbs' are in fact complements, not framing elements.

\section{CONCLUSION}

In this paper, I have provided evidence that Englebretson's (2003) analysis of complementation strategies in the colloquial Indonesian cannot be extended to Sundanese data. Despite the striking morphological and syntactic resemblance between Sundanese and Indonesian, what appears to be framing elements in Sundanese are evidently arguments of a predicate, thus clausal complements. In other words, analogues of what Dixon and Englebretson may claim as complementation strategies in Sundanese are arguable clausal complements. Future research may explore the extent to which Englebretson's (2003) analysis is tenable in other Indonesian neighboring languages such as Javanese, Madurese and Balinese.

\section{NOTE}

I would like to thank William D. Davies for all the insights and anonymous reviewers for very helpful comments on the earlier drafts.

\section{REFERENCES}

Arka, I. W. (2000). Control theory and argument structure: Explaining control into subject in Indonesian. Paper presented at the 4th International Malay and Indonesian Symposium, Jakarta.

Arka, I. W. \& and Manning, C. D. (1998). Voice and grammatical relations in Indonesian: A new perspective. In M. Butt \& T. H. King (eds.), The proceedings of the LFG '98 conference. Stanford: CSLI Publications.

Bisang, W. (2001). Finite vs. non-finite languages. In M. Haspelmath, E. König, W. Oesterreicher, \& W. Raibe (eds.), Language typology and language universals (pp. 14001413). Berlin/New York: Walter de Gruyter.

Bowden, J. (2001). Taba: A description of a South Halmahera language. Pacific Linguistics. Canberra: Australian National University Press.

Bresnan, J. W. (1970). On complementisers: Toward a syntactic theory of complement types. Foundation of language, 6, 297-321.

Bresnan, J. W. (1972). Theory of complementation in English syntax. MIT, Cambridge: Ph.D. dissertation.

Cole, P. \& Hermon, G. (1998). The typology of wh-movement: Wh-movement in Malay. Syntax, 1, 221-258.

Cole, P. \& Hermon, G. (2000). Partial wh-movement: Evidence from Malay. In U. Lutz, G. Müller, G., \& A. von Stechow (eds.), Wh-scope marking (pp. 101-130). Amsterdam: John Benjamins. 
Cole, P. \& Hermon, G. (2005). Subject and non-subject relativization in Indonesian. Journal of East Asian Linguistics, 14, 59-88.

Cole, P. \& Hermon, G., \& Aman, N. (2008). Headless relative clauses and wh questions in Singapore Malay. In L. Uyechi, \& L. H. Wee (eds.), Reality exploration and discovery: Pattern indication in language and life. Stanford, CA: CSLI.

Cristofaro, S. (1998). Deranking and balancing in different subordination relations: A typological study. Sprachtypologie und Universalienforschung, 51, 3-42.

Dixon, R. M. W. (1995). Complement clauses and complementation strategies. In F. R. Palmer (ed.), Grammar and meaning: Essays in honour of Sir John Lyons (pp. 175-220). Cambridge: Cambridge University Press.

Dixon, R. M. W. (2006). Complement clauses and complementation strategies in typological perspective. In R. M. W. Dixon \& A. Y. Aikhenvald (eds.), Complementation: A crosslinguistic typology (pp. 1-48). Oxford: Oxford University Press.

Englebretson, R. (2003). Searching for structure: The problem of complementation in colloquial Indonesian. Amsterdam: John Benjamins.

Foley, W. A. \& Olson, M. (1985). Clausehood and verb serialization. In J. Nichols (ed.), Grammar inside and outside the clause (pp. 17-60). Cambridge: Cambridge University Press.

Gil, D. (1997). When is a reflexive not a reflexive? Forms containing diri in the Riau and Irian dialects of Indonesian. In P. Cole, T. J. Huang, \& G. Hermon (eds.), Long distance reflexives, syntax and semantics 33 (pp. 83-117). New York: Academic Press.

Givón, T. (2001). Syntax, vol 1 \& 2. Amsterdam: John Benjamins.

Hardjadibrata, R. R. (1985). Sundanese: A syntactical analysis. Canberra: Australia National University, Department of Linguistics.

Johnson, S. (2006). Revisiting the structure of serial verb constructions. LSO Working Papers in Linguistics, 6, 39-48.

Kurniawan, E. (2013). Sundanese complementation. Ph.D. dissertation. The University of Iowa.

Kurniawan, E. \& William D. D. (2015). Finiteness in Sundanese. Oceanic Linguistics, 54, 1-16. Doi 10.1353/ol.2015.0010.

Kuswari, U. \& Hernawan. (2010). Sintaksis basa Sunda. Bandung: JPBD FPBS UPI.

Martins, A. M. (2001). On the origin of the Portuguese inflected infinitive: A new perspective on an enduring debate. In L. Brinton (ed.), Historical linguistics 1999: Selected papers from the $14^{\text {th }}$ International Conference on Historical Linguistics (pp. 207-222). Amsterdam: John Benjamins.

Müller-Gotama, F. (2001). Sundanese. Munchen: Lincom Europa.

Noonan, M. (1985). Complementation. In T. Shopen (ed.), Language typology and syntactic description: Complex constructions Vol. 2 (pp. 42-140). Cambridge: Cambridge University Press. 
Noonan, M. (2007). Complementation. In T. Shopen (ed.), Language typology and syntactic description (2nd ed.), Vol. II, Complex constructions (pp. 52-150). Cambridge: Cambridge University Press.

Polinsky, M. \& Potsdam, E. (2008). The syntax and semantics of wanting in Indonesian. Lingua $118,1617-1639$.

Ross, M. D. (2002). The history and transitivity of Western Austronesian voice and voicemarking. In F. Wouk \& M. Ross (eds.), The history and typology of Western Austronesian Voice Systems (pp. 17-62). Canberra: Pacific Linguistics.

Saddy, D. (1991). Wh-scope Mechanisms in bahasa Indonesia. In L. Cheng \& H. Demirdache (eds.), More papers on wh-movement (MITWPL 15). Cambridge, MA: MIT Press.

Sudaryat, Y., Prawirasumantri, A., \& Yudibrata K. (2007). Tata basa Sunda kiwari. Bandung: Yrama Widya.

Thompson, S.A. (2002). Object complements and conversation: Towards a realistic account. Studies in Language 26(1),125-164.

\footnotetext{
${ }^{1}$ Dixon (2006) criticizes Noonan's (1985) paper and its updated online version in that it fails to provide a necessary distinction between grammaticalized complement clauses and complementation strategies.

${ }^{2}$ Abbreviations used in the glosses include: 1: first person, 2: second person, 3: third person, ACC: accusative, APPL: applicative, AT: trigger, AV: actor voice, COMP: complementizer, CONT: continuous, DAT: dative, DEF: definite, DEM: demonstrative, DET: determiner, ERG: ergative, FUT: future, INFIN: infinitive, INFL: inflection, LOC: locative, MASC: masculine, NOM: nominative, NONVOL: nonvoluntary, NEG: negation, OBJ: objective, PAST: past, PART: particle, PERF: perfect, PL: plural, PROX: proximal, PT: patient trigger, PURP: purposive, PV: passive voice, REL: relativizer, REDUP: reduplication, SG: singular, SUBJ: subjunctive, and SUPER-ESS: super-essive.

${ }^{3}$ This characterization of an infinitive complement is not entirely true as languages like Portuguese are apparently counterevidence. Martins (2001), for instance, shows that inflected infinitives in the Modern Portuguese share some syntactic properties with finite clauses in taking nominative lexical subjects and displaying subject-verb agreement morphology. Compare the infinitive in (i) with the finite clause in (ii).

(i) $\mathrm{Vi} \quad$ [eles prenderem o ladrão].

saw-1SG they catch-INFL.INFIN-3PL the thief

'I saw them catch the thief.'

(ii) $\mathrm{Vi}$ [que eles prenderam o ladrão].

saw-1SG that they caught -3PL the thief

'I saw them catch the thief.'

The embedded clause in each example contains a nominative overt pronoun eles 'they' and the verb inflected for person.

${ }^{4}$ It remains unclear why a parataxis counts as a complement structure in light of the fact that it involves no subordination, as Noonan acknowledges himself.

${ }^{5}$ Kurniawan (2013) and Kurniawan and Davies (2015) note that these complementizers evince a number of distinct grammatical properties; one of which is the permissibility of an embedded subject.

${ }^{6}$ Englebretson (2003, p. 155) points out that Dixon's definition of complementation strategies is too restricted on clause-level grammatical relations that signal semantic relations between verbs. The definition has to be loosened in such a way that it incorporates discourse and pragmatic factors such as framing and stance.
} 